\title{
Cities' Role in Mitigating United States Food System Greenhouse Gas Emissions
}

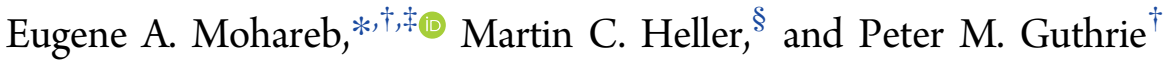 \\ ${ }^{\dagger}$ Centre for Sustainable Development, Department of Engineering, University of Cambridge, Cambridge CB2 1PZ, United Kingdom \\ ¥Construction Management \& Engineering, School of the Built Environment, University of Reading, Chancellor’s Building, Reading \\ RG6 6DF, United Kingdom \\ ${ }^{\S}$ Centre for Sustainable Systems, School of Environment \& Sustainability, University of Michigan, Ann Arbor, Michigan 48109-1041, \\ United States
}

\section{Supporting Information}

ABSTRACT: Current trends of urbanization, population growth, and economic development have made cities a focal point for mitigating global greenhouse gas (GHG) emissions. The substantial contribution of food consumption to climate change necessitates urban action to reduce the carbon intensity of the food system. While food system GHG mitigation strategies often focus on production, we argue that urban influence dominates this sector's emissions and that consumers in cities must be the primary drivers of mitigation. We quantify life cycle GHG emissions of the United States food system through data collected from literature and government sources producing an estimated total of $3800 \mathrm{~kg} \mathrm{CO} 2 \mathrm{e} /$ capita in 2010, with cities directly influencing approximately two-thirds of food sector GHG emissions. We then assess the potential for cities to reduce emissions through selected measures; examples include up-scaling urban agriculture and home delivery of grocery options, which each may achieve emissions reductions on the order of 0.4 and $\sim 1 \%$ of this total, respectively. Meanwhile, changes in Direct Food System GHG Emissions waste management practices and reduction of postdistribution food waste by $50 \%$ reduce total food sector emissions by 5 and $11 \%$, respectively. Consideration of the scale of benefits achievable through policy goals can enable cities to formulate strategies that will assist in achieving deep long-term GHG emissions targets.

\section{INTRODUCTION}

Current estimates suggest that urban areas contribute a disproportionate share to global greenhouse gas (GHG) emissions, with literature highlighting that $70 \%$ of energyrelated emissions, as well as $60-70 \%$ of all emissions from a consumption-based accounting approach, are attributable to the cities. ${ }^{1,2}$ In order to guide efforts to address this, recent research has explored the GHG mitigation potential from urban activities. $^{3-7}$ Ultimately, the success of city-driven GHG mitigation will dictate our success in meeting global longterm emissions reduction targets. ${ }^{5,6,8,9}$ The food system is one significant proportion of consumption-related emissions that cities must contend with.

At $20-30 \%$ of global GHG emissions, ${ }^{10,11}$ the substantial contribution of the food system to climate change necessitates that an increasingly urban population take action to reduce the carbon intensity of their consumption. ${ }^{11,12}$ Discussion of food system GHG emissions mitigation has predominantly focused on the production side of the food system, ${ }^{13-17}$ which is overwhelmingly $(\sim 95 \%)$ situated beyond urban spatial boundaries even when allocating peri-urban crops to cities. ${ }^{18}$ Available estimates of GHG emissions from urban food demand ${ }^{19-21}$ suggest that food contributes a large share of total consumption-based emissions, greater than road transport in some cases. ${ }^{20}$ However, focus is needed on what impact cities can have on food system GHG emissions, as well as what local governments can do to reduce these.

This research analyzes the U.S. food system by reframing food GHG mitigation policy as a predominantly urban (consumer) issue and provides national-level estimates of the scale of emissions reductions that could be realized through urban actions. Emissions within and beyond city boundaries (i.e., scopes 1-3) are impacted by decisions occurring within urban areas, which host more than $80 \%$ of the U.S. population; $^{22}$ coordinated efforts to reduce these emissions within the urban boundary are needed to achieve deep reductions in food sector GHG emissions. A quantification of direct GHG emissions from components of the food system is conducted, followed by an examination of the potential for urban policy to encourage food system GHG mitigation, estimating the scale of reductions that could be achieved. The primary purpose of this quantification exercise is to identify where the greatest opportunities are for GHG mitigation in cities toward a low-carbon food system.

Received: May 22, 2017

Revised: January 6, 2018

Accepted: March 27, 2018

Published: May 2, 2018 


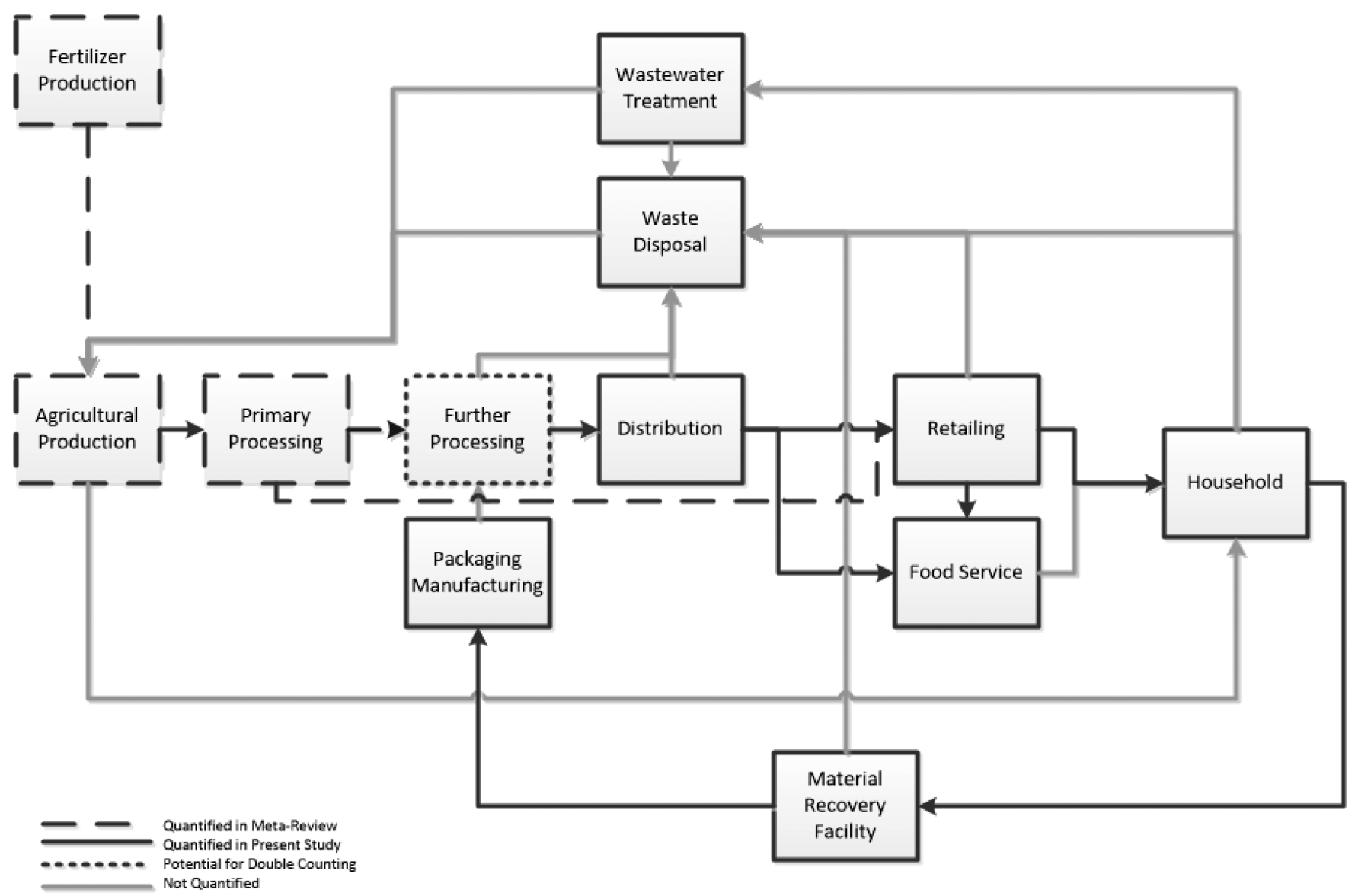

Figure 1. Process diagram of food system life cycle stages quantified in this analysis.

\section{METHODS}

This life-cycle study has the intended goal of identifying the GHG emissions associated with the provision of food to urban areas (defined as those with a population greater than 2500 people) within the U.S., along with an investigation of mitigation options that are available to municipal governments and urban residents. The scope of climate impacts from components considered throughout the life cycle of the U.S. food system is identified in the flowchart in Figure 1, estimating direct GHG emission sources from production to waste disposal and resource recovery. These include emissions from raw materials and farm-level production, as well as primary processing (i.e., milling grain to flour, canning of produce, milk pasteurization) quantified through a meta-review of life cycle assessment (LCA) studies. Emissions from secondary or further processing, distribution, retailing, food service, households, and waste disposal are quantified using U.S. government data sources. The system boundaries applied consider GHG emissions associated with energy consumption and fugitive emissions (e.g., refrigerants and landfill gas) directly attributable to food system activities/operations identified in Figure 1; emissions from supporting sectors (e.g., food manufacturing equipment fabrication, support services) are not quantified here. The functional unit applied to this attributional LCA is the average diet of the U.S. food consumer in 2010, with the data from the meta-review described below providing the foundation for the stated goal and scope, expanded upon using the various literature sources identified.
A complete description of GHG emission sources quantified here is provided in the Supporting Information (section S1), with an estimation of upper and lower data boundaries from the meta-review for each component of the food system, where data are available. The bottom-up food system GHG emissions accounting approach taken here is disaggregated by process and energy type (as well as refrigerant type) where possible, allowing for the consideration of impacts of decisions currently made within urban areas on total food system emissions and specific supporting sectors (e.g., packaging, refrigerants, and waste management). Furthermore, quantification of the emissions reduction potential for mitigation measures are described in the Supporting Information (section S2). The quantification approach taken here allows for the modification of specific elements within the food system (e.g., animal product substitution, and alternative waste management processes), to determine their scale of GHG mitigation. This allows an estimation of the potential policy impacts that can be realized by city governments and how collectively these might affect overall GHG emissions from food system operations.

Meta-Review of Life Cycle Assessments. There is currently no comprehensive and authoritative database of food-related environmental impacts. Thus, the approach taken here follows a meta-review of published LCA data to arrive at representative carbon footprint values for the diversity of food commodities consumed in the United States. Results are drawn from a variety of sources (as described by Heller and Keoleian, ${ }^{23}$ with refinements described below and in the Supporting Information section S1.1), compiled by food product, and averaged across comparable food type for 99 


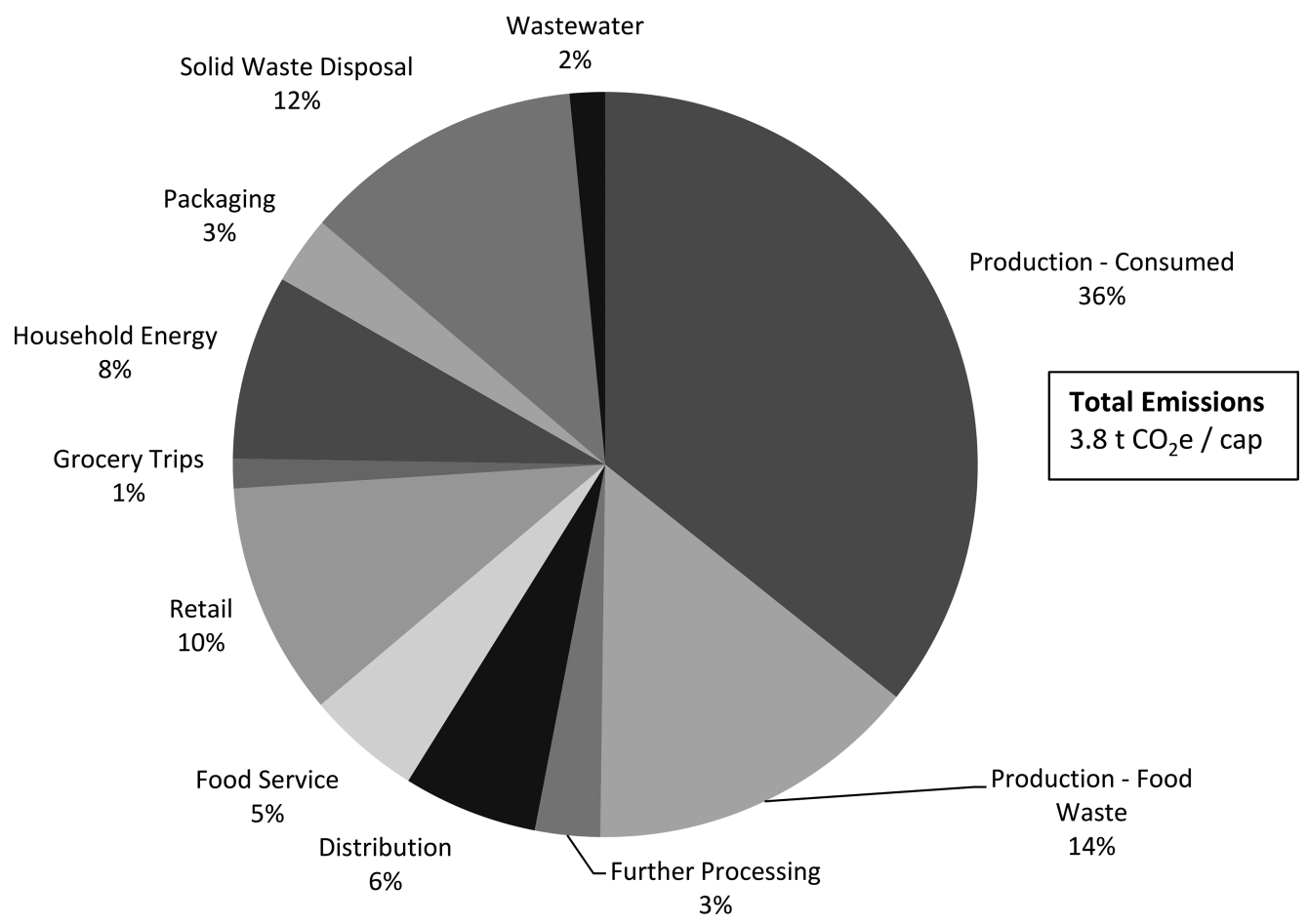

Figure 2. Contribution of various components to U.S. food system greenhouse gas emissions.

commodities. U.S.-based data is limited; thus, this meta-review includes data from other developed countries. These sources include studies representing a variety of countries of origin, climatic conditions, transportation distances, and production methods; therefore, they are intended to provide a reasonable range of expected values rather than a definitive result for each food type.

To estimate emissions associated with production of the U.S. diet, the above-described meta-review was linked to the Loss Adjusted Food Availability (LAFA) data series. ${ }^{24}$ LAFA serves as a useful proxy for per capita food consumption in the United States. The food availability series measures the use of basic food commodities (e.g., wheat, beef, fruit, and vegetables) by tracking their "disappearance" in the U.S. marketplace. For most commodities, the available supply is the sum of production, imports and beginning stocks, minus nonfood use (feed and seed, industrial uses), exports, and ending stocks for a given calendar year. In the Loss Adjusted data series, the food availability data for over 200 commodities are modified by percent loss assumptions at the primary level, retail/institution level, and consumer level. Retail losses include dented cans, unpurchased holiday foods, spoilage, and the culling of blemished or misshaped foods. Consumer losses include spoilage, cooking shrinkage, and plate waste. Note that the U.S. Department of Agriculture (USDA) estimates report only food losses and do not differentiate between wastes (such as plate scraps) that could be avoided through behavioral change and losses (such as moisture losses during cooking) that are largely unavoidable.

The meta-review from Heller and Keoleian ${ }^{23}$ was refined for the top commodity contributors (defined as those that contributed more than $50 \mathrm{~kg} \mathrm{CO} 2 \mathrm{e} / \mathrm{cap}$ ) or those that had a substantial variation across studies (defined as greater than 100 $\mathrm{kg} \mathrm{CO} 2 \mathrm{e} / \mathrm{cap}$ ). This was to ensure that error introduced from double counting was reduced for large sources of emissions. The commodities included in this refinement were beef, chicken, pork, cheese, fluid milk, eggs, and added sugars and sweeteners. For these foods, a further review of LCA emission factors was conducted to limit the studies to only include those whose boundaries extend up to the primary processing stage. Additionally, added sugars and sweeteners are represented by a consumption-weighted average of honey, white sugar, and high fructose corn syrup.

Quantification of GHGs Occurring after Primary Processing. Emissions estimates can be generally described in the equation

$$
\text { GHG emissions }=\text { activity data } \times \text { emissions factor }
$$

The description of these calculations for each sector is provided in the Supporting Information (sections S1.2-S1.9). Activity data can be broadly identified as those pertaining to energy consumption, which have been estimated or scaled as described in sections S1.2-S1.9, and emissions factors are the emissions intensities provided in Table S17. Energy demand data were generally compiled from U.S. government sources, coupled with industrial and peer-reviewed literature, to quantify GHGs associated with each stage identified in Figure 1. Data sources include U.S. National Household Travel Survey ${ }^{25}$ and the U.S. Energy Information Administration's (U.S. EIA) Manufacturing, Commercial and Residential Building Energy Consumption Surveys. ${ }^{26-28}$ Process-related GHG emissions from waste treatment are calculated using U.S. Environmental Protection Agency (U.S. EPA) ${ }^{29}$ and industry ${ }^{30}$ waste disposition estimates of waste managed by treatment type (e.g., landfill, composting, and anaerobic digestion), considered for three segments of the food system (farm-gate-to-retail, retail, and household). Refrigerant data were taken from the U.S. National Inventory Report submitted in $2014^{31}$ and allocated to specific sectors, as described in the Supporting Information.

Road transportation data for distribution between further processing to households is also estimated, with the exception of household trips for food service sector meals (as highlighted 


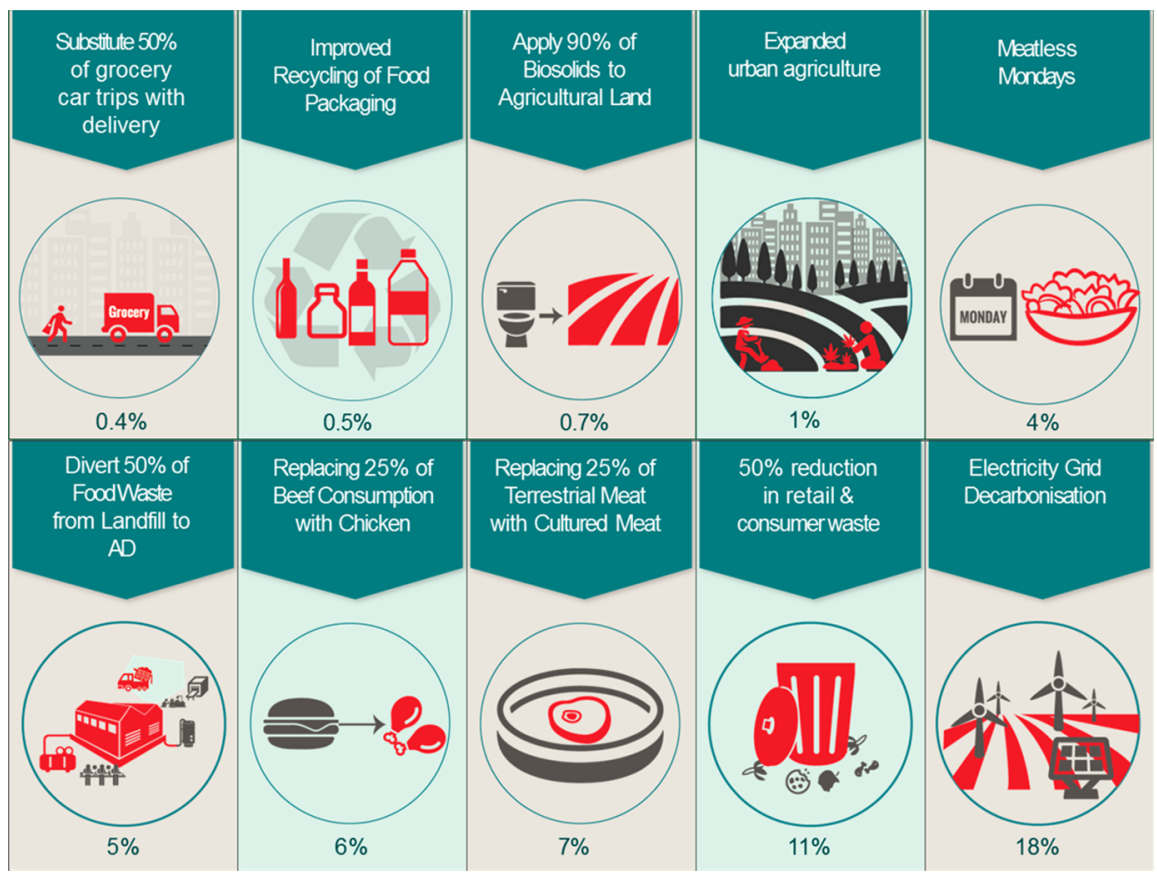

Figure 3. Estimates of greenhouse gas reduction potential of various measures associated with the U.S. food system, relative to 2010 emissions.

in Figure 1). Transportation emissions occurring from other modes of transportation used beyond the components covered in the meta-review of LCA studies are not included.

GHGs from food waste disposal in landfill uses a methane commitment quantification approach based on 1996 IPCC guidelines, ${ }^{32,33}$ while those from anaerobic digestion use 2006 IPCC guidelines, ${ }^{34}$ and composting applies emissions factors from literature estimates. ${ }^{35}$ Food loss and related emissions occurring between farm and primary processing are assumed to be captured in individual LCA studies, with any losses between primary processing and retail assumed to be negligible.

Emissions factors and sources are presented in the Table S17, along with relevant global warming potential for refrigerants, methane, and nitrous oxide. Transportation emissions related to packaging are calculated using the emissions factors from the U.S. EPA Waste Reduction Model (WaRM). ${ }^{36}$

Estimation of Food System GHG Reduction Potential by Cities. A selection of policies including those that are currently being discussed at the municipal level ${ }^{37}$ are used to assess where opportunities for food system GHG mitigation lie in cities; these are detailed in the Supporting Information (Section S2). In each case, upstream and downstream emissions associated with a mitigation measure are considered. For example, the GHG reduction potential for urban agriculture assume reductions in transportation, cold storage in distribution, waste reduction along the supply chain, and associated landfill gas emissions from this avoided waste. Reclaimed nutrients from wastewater sludge that are diverted from landfills are assumed to displace inorganic fertilizers and reduce landfill gas emissions.

\section{RESULTS AND DISCUSSION}

Urban Food System GHG Emissions. It is estimated here that the average U.S. citizen's diet in 2010 resulted in the release of $2700-5900 \mathrm{~kg} \mathrm{CO}_{2} \mathrm{e} /$ capita, with a central estimate of $3800 \mathrm{~kg} \mathrm{CO} 2 \mathrm{e}$ /capita (see Figure 2 for details of emissions sources and Table 1 for details on data uncertainty). This central estimate applies either average, default or "best guess" values used in calculating the contributions of the food system components described (see section S1 of the Supporting Information for further details for each component). All percentages quoted henceforth are applied to this estimate, which is comparable with other estimates of U.S. food consumption's carbon footprint. ${ }^{38,39}$ "Production-Food Waste" represents emissions associated with the production of food (including primary processing) that is eventually wasted at some stage in the food system, whereas "ProductionConsumed" emissions are those that result from food products that are eventually consumed. Further processing emissions are from food manufacturing operations beyond primary processing (e.g., milling of grains and pasteurization of milk), distribution includes cold chain energy and road freight (along with fugitive refrigerant emissions associated with these), while packaging represents the embodied emissions of food packaging materials.

The majority $(\sim 50 \%)$ of the $3800 \mathrm{~kg} \mathrm{CO}_{2} \mathrm{e} /$ capita estimate occurs through the production of food and associated primary processing of commodities (e.g., conversion of agriculture products to flour, canned/frozen produce, dried goods, and dairy product manufacture). However, approximately $14 \%$ of the total is attributed to the production stage (pre-farm-gate) of food that is eventually wasted post-farm-gate, predominantly by activities in urban areas. The next largest contribution comes from the disposal of food waste in landfills at roughly $500 \mathrm{~kg}$ $\mathrm{CO}_{2} \mathrm{e} /$ capita (12\%), emphasizing the need to both reduce food waste and divert any remaining waste from landfills. This is followed by household emissions, which are responsible for approximately $8 \%$ of the total, suggesting the value in promoting the improvement in the efficiency of the home refrigeration and cooking appliance stock, as well as mitigating the release of refrigerants upon their disposal. Further gains could be realized here (and other segments of the food system) by using lower GWP refrigerants and reducing the carbon intensity of the electricity grid and cooking fuels. 
Table 1. Ranges of Estimates from Food System Components

\begin{tabular}{|c|c|c|c|}
\hline & $\begin{array}{c}\text { average/central } \\
\text { estimate }\end{array}$ & $\min ^{a}$ & $\max ^{a}$ \\
\hline $\begin{array}{l}\text { production \& primary } \\
\text { processing (meta-review) }\end{array}$ & 1936.0 & 1158.0 & 3366.2 \\
\hline grain products & 57.6 & 35.2 & 75.6 \\
\hline fresh fruit & 33.2 & 13.7 & 68.5 \\
\hline processed fruit & 40.4 & 32.8 & 54.0 \\
\hline fresh vegetables & 46.9 & 12.6 & 231.6 \\
\hline processed vegetables & 53.8 & 34.8 & 82.1 \\
\hline fluid milk & 104.4 & 74.5 & 136.8 \\
\hline other dairy products & 246.6 & 202.7 & 301.6 \\
\hline meat & 1096.5 & 607.4 & 1918.1 \\
\hline fish and seafood & 45.8 & 10.0 & 84.8 \\
\hline eggs & 47.4 & 20.4 & 100.7 \\
\hline nuts & 8.2 & 5.7 & 10.8 \\
\hline $\begin{array}{l}\text { added sugar and } \\
\text { sweeteners }\end{array}$ & 39.5 & 39.5 & 39.5 \\
\hline added fats and oils & 115.5 & 68.7 & 262.0 \\
\hline secondary processing & 109.03 & $\mathrm{~N} / \mathrm{A}$ & $\mathrm{N} / \mathrm{A}$ \\
\hline packaging materials & 114.12 & 77.97 & 131.22 \\
\hline distribution & 238.50 & 214.55 & 264.50 \\
\hline retail & 390.60 & 370.79 & 410.41 \\
\hline food service & 179.39 & $\mathrm{~N} / \mathrm{A}$ & $\mathrm{N} / \mathrm{A}$ \\
\hline grocery trips & 49.41 & 8.05 & 292.96 \\
\hline household & 309.65 & $\mathrm{~N} / \mathrm{A}$ & $\mathrm{N} / \mathrm{A}$ \\
\hline landfill-food & 445.04 & 164.71 & 745.12 \\
\hline landfill-sludge & 26.32 & 18.24 & 36.72 \\
\hline wastewater & 59.16 & $\mathrm{~N} / \mathrm{A}$ & $\mathrm{N} / \mathrm{A}$ \\
\hline composting $^{b}$ & 3.24 & $(4.71)$ & 9.31 \\
\hline emissions & 4.75 & 0.40 & 9.51 \\
\hline $\begin{array}{l}\text { fertilizer offset from } \\
\text { composting }\end{array}$ & -0.66 & -0.08 & -1.72 \\
\hline $\begin{array}{l}\text { carbon stored in land } \\
\text { application }\end{array}$ & -0.85 & -0.12 & -3.39 \\
\hline anaerobic digestion $^{b}$ & -0.09 & -0.36 & 0.16 \\
\hline emissions & 0.15 & 0.11 & 0.22 \\
\hline $\begin{array}{l}\text { carbon stored in land } \\
\text { application }\end{array}$ & -0.14 & -0.03 & -0.28 \\
\hline $\begin{array}{l}\text { fertilizer offset from } \\
\text { composting }\end{array}$ & -0.07 & -0.03 & -0.12 \\
\hline offset from electricity & -0.03 & -0.00 & -0.07 \\
\hline total emissions $\left(\mathrm{kg} \mathrm{CO}_{2} \mathrm{e} / \mathrm{cap}\right)$ & 3846.46 & 2669.71 & 5886.43 \\
\hline
\end{tabular}

As shown in Figure 3, we estimate that approximately onethird (36\%) of food system GHG emissions in 2010 were associated with agricultural operations that provide food that is ultimately consumed; this share can strictly be influenced by production-side mitigation approaches (assuming no change in average dietary composition). These would include changes in production practice, agricultural products yielded, and production site. ${ }^{14}$ Post-farm-gate waste and the remainder of emissions from the food system (around two-thirds of the total) must be addressed along the supply chain, and within consumption and waste management systems; we argue that these can generally be considered as GHG emissions that urban areas (and their resident consumers) are best positioned to address. Furthermore, shifts in diet can influence producer side emissions (i.e., reduced demand for animal products); therefore, there is scope for consumers who are predominantly in cities to affect these production-related emissions as well.
Mitigation Measures. A collection of urban measures to reduce GHG emissions from the food system is summarized in Figure 3. These measures could be pursued through municipal policy to ensure long-term reductions in the broader food system. It is not suggested that municipal governments alone are responsible for pursuing these; rather, through policy advocacy at various levels of government, cooperation with industrial actors, and campaigns to influence dietary choices, food system GHG reductions could be realized by stakeholders in these subsectors that operate within the spatial boundaries of urban areas. It should be noted that the reduction potentials presented below are not assumed to be additive; net food system GHG reductions may be higher or lower when combining the actions below due to relationships and indirect effects not quantified or modeled here. Finally, the practicality (or even desirability) of achieving the measures suggested below is not the focus of the discussion; rather, the intention here is solely to estimate the scale of benefits that might be realized if certain policy goals are pursued.

Urban Agriculture. Urban agriculture is often promoted as a strategy for mitigating GHG emissions in the food system, ${ }^{17,37}$ and the model developed here allows an exploration of potential carbon benefits. A scenario is developed where openfield rain-fed urban agriculture is scaled up to occupy $50 \%$ of vacant land within urban centers, resulting in $17 \%$ of U.S. produce demand being met by production in urban areas, as well as a reduction in transportation and distribution demands of produce within the food system (as well as a corresponding reduction in retail-sector waste), while the inputs of production are assumed to be the same. In this case, we estimate that a reduction of $10 \mathrm{~kg} \mathrm{CO}_{2} \mathrm{e} /$ capita (or $0.25 \%$ of the total) could be achieved. A greater degree of GHG emissions reduction is possible if cold chain refrigeration (i.e., electricity consumption and refrigerant loss) were avoided by this urban production; we estimate that this could contribute up to $1.2 \%$ reduction relative to 2010 food sector emissions. These may be an optimistic level of emissions mitigation from open-field agriculture, as considerations such as vacant land ownership, site quality (i.e., associated soil, water, and solar resources), and implications of seasonality (and the associated temporal misalignments of production/consumption) are not considered as in other urban agriculture analyses. ${ }^{40,41}$

Waste Management. Cities have substantial influence over local waste management. ${ }^{37}$ Food waste is a focal point for food system sustainability, with initiatives such the U.S. Department of Agriculture's Food Waste Challenge, ${ }^{42}$ the Food Waste Reduction Alliance, ${ }^{43}$ and the Milan Urban Food Policy Pact. ${ }^{44}$ In addition to the potential cost savings and improved food access, food waste reduction initiatives represent a significant opportunity for GHG mitigation through waste-focused policy, industry campaigns, or alternative waste management approaches.

Approximately $12 \%$ of the food system's emissions in 2010 were associated with the landfilling of food waste and biosolids from wastewater treatment; over $80 \%$ of this is attributable to urban management of municipal solid waste (household and retail food waste, excluding nonedible components). A reduction in food waste has the potential to lower demandrelated GHG emissions upstream, as well as landfill gas emissions downstream. For example, assuming emissions from other life cycle stages are held constant, meeting the UN Sustainable Development Goal to halve food waste from consumers and retailers by 2030 (SDG 12.3) could provide a 


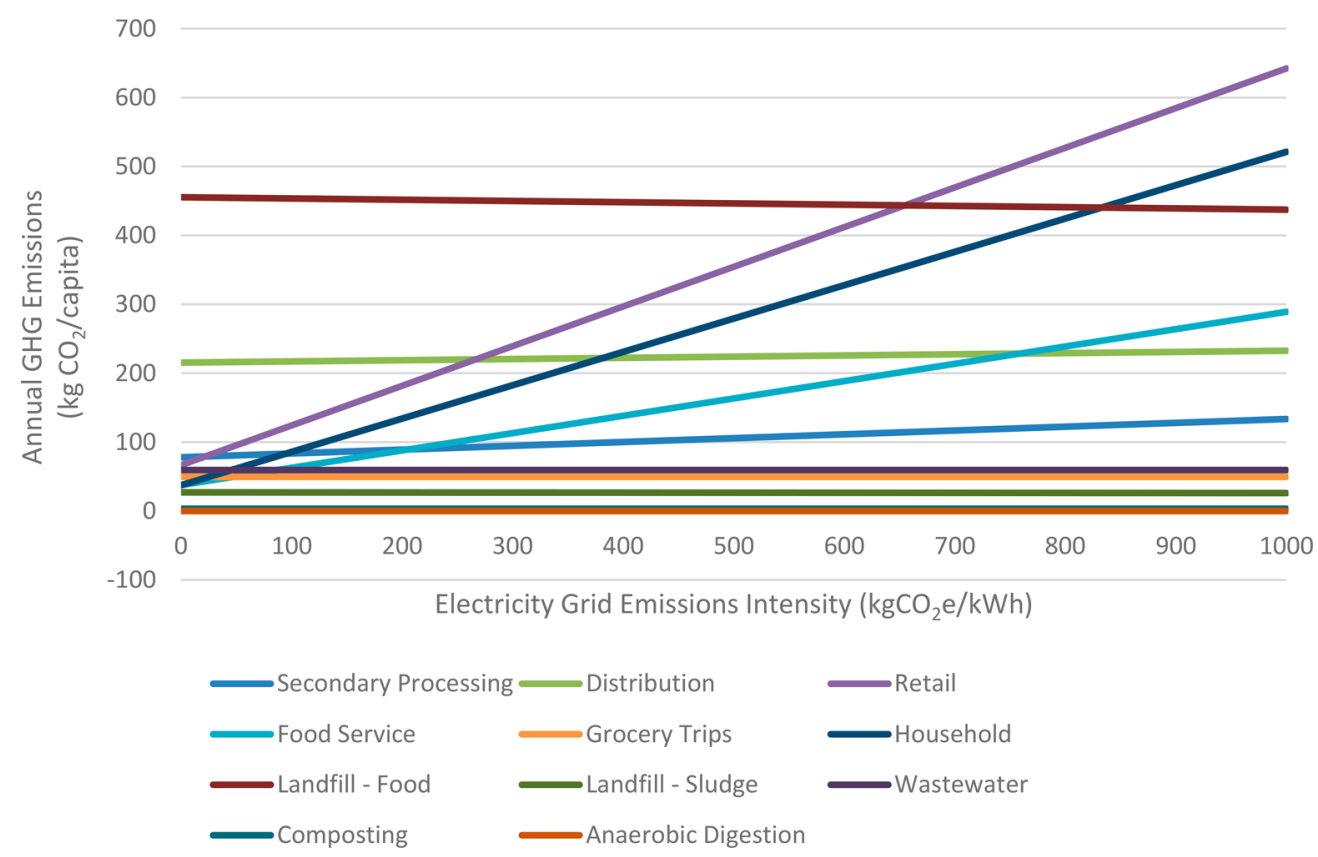

Figure 4. Sensitivity analysis of electricity grid emissions intensity associated with various components of food system.

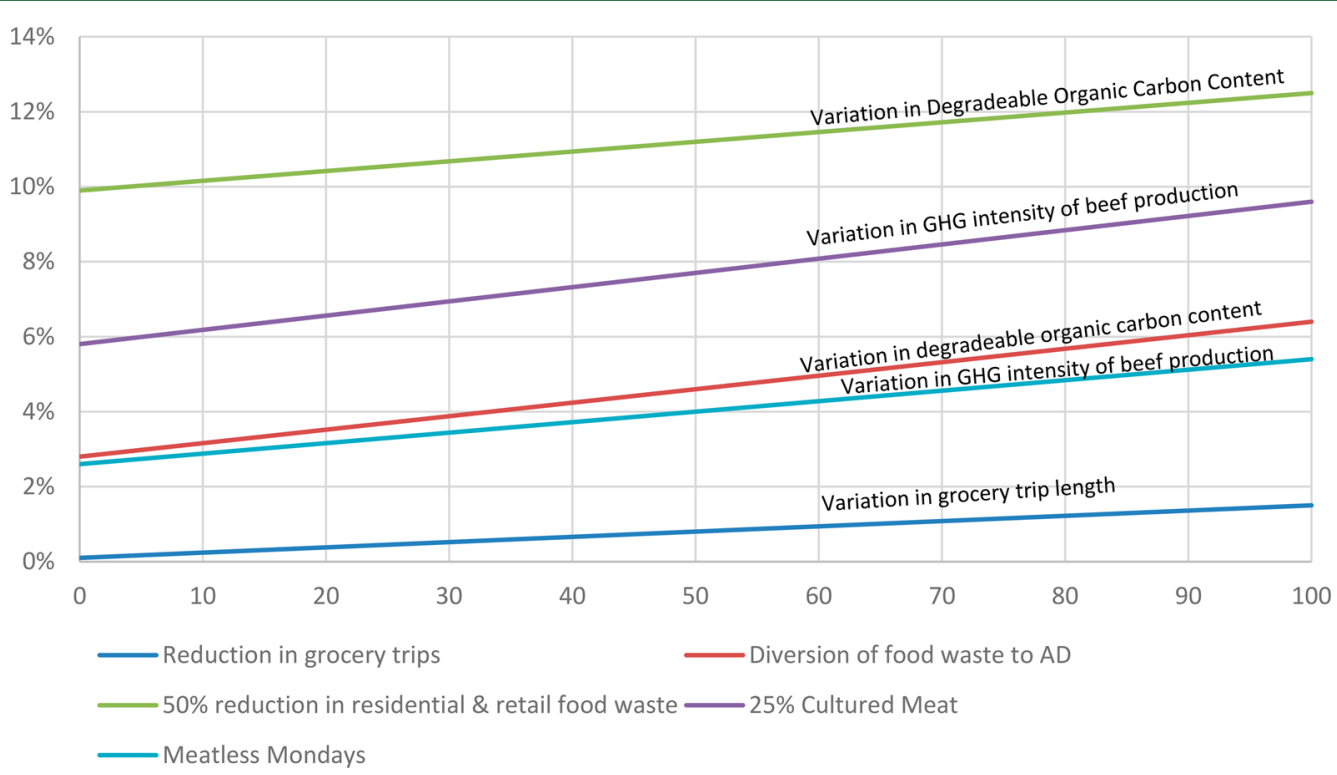

Figure 5. Sensitivity analysis of benefits realized for selected mitigation measures.

Table 2. Parameters Used in Sensitivity Analysis for Food System Components and Selected Mitigation Measures ${ }^{a}$

\begin{tabular}{|c|c|c|c|}
\hline parameter & current & $\underset{(0)}{\operatorname{minimum}}$ & $\begin{array}{c}\operatorname{maximum} \\
(100)\end{array}$ \\
\hline $\begin{array}{l}\text { electricity grid emissions factor } \\
\qquad\left(\mathrm{kg} \mathrm{CO} \mathrm{CO}_{2} \mathrm{e} / \mathrm{kWh}\right)\end{array}$ & 0.56 & 0.0 & 1.0 \\
\hline mean distance to grocery $(\mathrm{km})$ & 2.9 & 1.0 & 10.3 \\
\hline $\begin{array}{l}\text { degradable organic carbon content, food } \\
\text { waste }(\%)\end{array}$ & 15 & 8 & 20 \\
\hline $\begin{array}{l}\text { carbon intensity of beef production } \\
\left(\mathrm{kg} \mathrm{CO} \mathrm{CO}_{2} \mathrm{e} / \mathrm{kg}\right)\end{array}$ & 34.4 & 16.8 & 58.4 \\
\hline
\end{tabular}

cascade of emission avoidance throughout the food system by reducing demand for transport, processing, storage, and waste within the supply chain, resulting in an $\sim 400 \mathrm{~kg} \mathrm{CO} 2 \mathrm{e} /$ capita reduction ( $11 \%$ of the total). This assumes that for each unit of mass of food waste that is avoided, the upstream production, processing, and distribution requirements are also avoided. As one would expect, greater benefits would be realized by avoiding the waste of animal products due to their carbon intensity, but food products are assumed to be preserved according to the current distribution of consumption.

Alternative waste management options provide another approach to reduce GHG emissions associated with food waste, with anaerobic digestion $(\mathrm{AD})$ being assessed to provide substantial reductions. ${ }^{45,46}$ Even if the quantity of food wasted were to remain constant, increasing food waste diversion from landfill to $\mathrm{AD}$ facilities to $50 \%$ of the total would lead to a $5 \%$ reduction $\left(\sim 210 \mathrm{~kg} \mathrm{CO} \mathrm{CO}_{2} \mathrm{e} /\right.$ capita $)$ of food system emissions when electricity offsets (2010 grid emissions factor) and nutrient recovery are considered. Additionally, modest 
improvements in the recycling of food packaging (see Table S19 in the Supplementario materials for more information) could also mitigate food sector GHGs, by $\sim 20 \mathrm{~kg} \mathrm{CO}_{2} \mathrm{e} /$ capita $(0.5 \%$ of the total). If cities were to improve the fraction of biosolids from wastewater that are field applied (from 55\% to $90 \%$ ) so that nutrients from biogenic sources replace synthetic fertilizers, then a reduction of $30 \mathrm{~kg} \mathrm{CO} /$ capita (0.7\%) could be realized, mostly through landfill gas mitigation; it should be noted that this is in addition to the primary benefit of improved nutrient recovery. Concerns over organic pollutants in wastewater must also be addressed. ${ }^{47}$

Grocery Trips. Cities can also consider the influence of urban form and mixed land use, with grocery retailers within close proximity of residences, on food sector emissions; for example, reductions associated with the vehicle trips to collect food (the last mile of the food supply chain; i.e., retail to household). This could be achieved through better spatial planning to encourage walkability or, in the short term, through greater use of grocery delivery. ${ }^{48}$ We estimate grocery trips may represent $\sim 70 \mathrm{~kg}$ $\mathrm{CO}_{2} \mathrm{e} /$ capita in annual emissions to the food system (ignoring multipurpose trips). However, if a longer mean trip distance between household and grocery stores, more frequent trips and a greater share accessed by applied (see Table S12 in the Supplementary Information), then this total could increase to $320 \mathrm{~kg} \mathrm{CO} \mathrm{CO}_{2} \mathrm{e} / \mathrm{cap}$. This underscores the need for cities to assess their residents' transportation behavior. Using the lower estimate of $70 \mathrm{~kg} \mathrm{CO}_{2} \mathrm{e} / \mathrm{cap}$, a reduction of $0.4 \%$ of the total (15 $\mathrm{kg} \mathrm{CO} 2 \mathrm{e} / \mathrm{cap}$ ) could be achieved by reducing the number of vehicle trips to collect groceries by $50 \%$ and replacing these with grocery delivery.

Energy Supply. Opportunities exist for urban areas to influence the composition of the electricity grid (e.g., through renewable energy financing or by purchasing renewable energy credits) and facilitate the transition to low-emissions vehicles (e.g., support of EV charging infrastructure), indirectly supporting the adoption of lower carbon alternatives within broader policy and market trends. A substantial share of total food sector emissions can be addressed through the broader decarbonization of fuels and the electricity grid, as proposed elsewhere. ${ }^{49}$ Just considering U.S. energy consumption occurring after primary processing (from further processing, food service, distribution, retail, trips to retail, and household preparation, but excluding packaging), 700 and $300 \mathrm{~kg} \mathrm{CO}_{2} \mathrm{e} /$ capita in 2010 are attributable to electricity and fuels (for transportation, processing, and heating), respectively (corresponding to $18 \%$ and $8 \%$ of the total). From our estimates, most electricity emissions are associated with household consumption, while the majority of fuel consumption occurs during distribution. Eliminating the fossil carbon content of these energy sources will translate to substantial reductions in the climate impact of the food system.

Diet. Finally, diet has been identified as a strong driver of food sector GHG emissions, ${ }^{23,50,51}$ in addition to other resource demands (e.g., water footprint); a previous study has shown that shifting to an ovo-lacto vegetarian diet would reduce carbon emissions by $30 \%$ relative to a "typical" 2000 calorie USDA Dietary Guideline diet. ${ }^{23}$ As well, an analysis of diets from various Mediterranean cities shows that an ovo-lacto vegetarian diet reduced production-related water consumption by $30-50 \%$ relative to those that where terrestrial and aquatic animals are consumed. ${ }^{52}$ In this study, we estimate that $77 \%$ of production and primary processing emissions in the American diet in 2010 are attributable to animal-based food consumption.
Cities have succeeded in to developing policies that aim to mitigate health issues associated with diets (e.g., soft drink taxes in Berkeley, CA, and Philadelphia, PA), ${ }^{53,54}$ with a similar case to be made for the health benefits of reducing red meat products. ${ }^{55}$ A number of initiatives exist that encourage reduced consumption of animal products; if the goal of the "Meatless Monday" campaign were widely achieved, resulting in a $1 / 7$ reduction in U.S. terrestrial and aquatic animal products consumption (replaced by whole legumes and relative to a 2010 dietary baseline), then we estimate a $\sim 4 \%$ reduction of food system GHGs could be realized. Two more unconventional dietary options, edible mealworm ${ }^{56}$ and cultured meat products, ${ }^{57}$ could also assist in achieving GHG reductions; replacing $25 \%$ of terrestrial meat consumption in 2010 with these alternatives leads to 1 and $7 \%$ reduction in total emissions, respectively. These only consider emissions from production and do not account for differences in distribution, storage, and preparation. Even simply replacing $25 \%$ of beef production (assuming a direct relationship with consumption) with chicken achieves a $6 \%$ reduction of food sector emissions. In addition to the health and climate benefits mentioned, preference-based mitigation approaches have also been shown to potentially lower food prices and address land scarcity. ${ }^{58}$

Policy Implications. To date, there has been a strong focus on production systems (including urban agriculture) to address food-related GHG emissions; however, this can draw attention away from the many important components of the food system that urban food consumers must address to achieve deep overall emission reductions. Municipal governments have a role to play in facilitating the switch to a low-carbon food system, whether it be through greater diversion of food waste, longterm planning for greater density, promotion of renewable electricity (e.g., through the purchase of renewable energy certificates, power purchase agreements, or community solar initiatives), ${ }^{59,60}$ promotion of alternative sources of protein, levies on carbon-intensive food products, facilitation of grocery delivery, or supporting energy efficiency in food service/retail. ${ }^{61}$ Opportunities for mitigation policy are numerous, with many of these having other positive cobenefits, such as lower costs, reduced waste, as well as improving health, local walkability, and food system resilience. Effective urban policy for wholesystem GHG mitigation (i.e., including scope 3 emissions) must consider the influence of local consumption and the numerous food system components to distribute, process, preserve, and dispose offood, as well as how to encourage lower-impact behavior and activities.

As a point of comparison for the impacts of the policy goals discussed above, reducing 2010 residential natural gas consumption by $25 \%$ or road transportation by $10 \%$ would result in emission reductions of 210 and $480 \mathrm{~kg} \mathrm{CO}_{2} \mathrm{e} /$ capita, respectively. These are comparable in scale to diverting $50 \%$ of food waste to anaerobic digestion (for the former) or avoiding $50 \%$ of retail and consumer food waste.

Uncertainty and Sensitivity. A range of results is provided for many of inputs described in the Supporting Information sections S1.1-1.9. A summary of each sector's contribution, as well as the range obtained from the meta-review (where available) for each sector are listed in Table 1. The average/ central estimates apply either the average or default values of various parameters, representing the "best guess" for emissions, and is in line with other estimates provided in the literature. However, uncertainty associated with production systems and data sources are also provided and are worthy of discussion. 
Furthermore, sensitivity analysis of the more notable measures (presented in Figure 3) is also relevant in order to inform whether the scale of reduction estimates are transferable to other jurisdictions.

Focusing on the commodities, there is considerable variation across literature-reported emissions for important meat and dairy commodities, which are the dominant contributors to GHG emissions. This reflects, in part, real variation in production practices for these foods, as well as uncertainty introduced by data quality and methodological choices. As the underlying LAFA per-capita food consumption data does not differentiate production practices, a more refined assignment is not possible in this study. U.S.-specific data are not available for all commodities, and reliance on single or limited U.S.-specific studies may introduce biases that do not represent the true variability that is likely to be seen across production practices. Further uncertainty analysis of these commodities is provided in Figure S2.

Looking beyond the dietary uncertainty, implications of grid emissions intensity on the baseline data are presented in Figure 4 , applying the maximum/minimum values provided in Table 2 . Production systems are not included in this figure as there is not sufficient energy demand disaggregation for these commodities in the meta-review to enable an examination of sensitivity to electricity emissions; as a result, this is a fixed quantity (this would be represented by a straight line at approximately $2000 \mathrm{~kg} \mathrm{CO} \mathrm{CO}_{2} \mathrm{e}$ /capita). Emissions calculations for wastewater treatment and packaging material production are also fixed for this reason (60 and $100 \mathrm{~kg} \mathrm{CO}_{2} \mathrm{e} /$ capita, respectively), while grocery trips are not affected as electric vehicles were a negligible component of personal transportation energy consumption in 2010. However, the implications for sectors such as retail, households, and food service is substantial given their reliance on electricity as secondary energy source.

The benefits realized by mitigation measures presented in Figure 3 are also sensitive to a number of parameters. A selection of parameters are tested below as they can affect the relative benefit of the relevant mitigation option, presented in Table 2 (where 0 is the minimum value and 100 is the maximum value). The results of varying these single parameters are seen in Figure 5 for the mitigation measures that were judged to be subject to the greatest degree of uncertainty, as well as an associated parameter which would have substantial implications for the resulted mitigation benefit.

The range of mitigation benefits that could be achieved under this parametric analysis was as low as $1.4 \%$ (for grocery trip avoidance) and as high as $3.8 \%$ (for the introduction of cultured meat). A few points can be taken away from this, one of which being the importance of local production practices for beef; for example, in a food system where beef is predominantly sourced from dairy cattle, the net benefit for dietary measures would decrease. As well, if wasted food products were those with a higher moisture content (e.g., produce), then this would also reduce the benefit of diverting these from landfill.

Other parameters will also affect the degree of benefit to the total system that mitigation measures will have, such as current levels of beef consumption, proportions of households using natural gas for cooking, or agricultural practices followed by local producers, among many other factors. Overall, reflection needs to be made not only at the city level to consider where local conditions may vary from the assumptions used here, but also at the individual level to identify where food choices might be contributing to GHG emissions and how these can be changed toward low-carbon eating.

Omissions. As mentioned, this research does not attempt to quantify emissions from secondary industries (e.g., services to the food system and embodied emissions of materials used) associated with the various stages of the food system, as would be possible using an input-output LCA approach. As a result, this does not provide as complete an account of climate impacts as would be provided had these been included. Given that these tend also to lie within urban influence, it can be expected that their inclusion would further highlight the need for broader mitigation measures in supporting commercial and industrial sectors within cities.

Additionally, as mentioned above, double-counting from the meta-review of LCA studies is possible, but it has been largely addressed through the selection of literature that does not include stages beyond primary processing. Furthermore, no attempt is made to quantify the rebound effect or other such unintended consequences from these mitigation measures, which have the potential to counteract the suggested GHG emissions reductions. ${ }^{62}$ This remains a challenge that governments at all levels must address (e.g., through adequate carbon pricing) to ensure durable reductions in emissions can be realized.

Finally, the estimates of the urban GHG emission reductions possible from the measures identified above should be seen as approximations using highly aggregated data, with many assumptions (stated in the Supporting Information) that influence the baseline and anticipated benefit. Also, as with all complex systems, unforeseen consequences could diminish the net GHG reductions (e.g., even with a dramatic shift in diet resulting, emissions reductions may be limited due to a shift toward the exportation of animal products). While we expect that the errors attributable to this aggregation would not result in changes to the order of magnitude of emissions benefits, it is important to investigate local conditions and practices to determine the ultimate scale of benefits that can be realized. Meanwhile, the complexity of the food system underscores the need for a global collaborative effort to reduce GHG emissions to avoid carbon leakage of this nature.

\section{ASSOCIATED CONTENT}

Supporting Information

The Supporting Information is available free of charge on the ACS Publications website at DOI: 10.1021/acs.est.7b02600.

Description of the assumptions, parameters and inputs of individual GHG calculations associated with estimates from each component of the food system evaluated here. Further detail provided on assumptions associated with estimates of the scale of urban GHG mitigation achievable throughout the food system (PDF)

\section{AUTHOR INFORMATION}

\section{Corresponding Author}

*E-mail: e.mohareb@reading.ac.uk.

ORCID

Eugene A. Mohareb: 0000-0003-0344-2253

Notes

The authors declare no competing financial interest. 


\section{ACKNOWLEDGMENTS}

This research has been funded in part by the Natural Sciences and Engineering Research Council of Canada. We thank the following people for their assistance on this paper: Sybil Derrible and Tim Dixon for their helpful comments; Dave Godwin, Carole Cook, Mausami Desai of the U.S. EPA for assistance on GHG data from refrigeration; Hank Sattlethight of the Aluminum Association for data on aluminum use; and Jennifer Killinger and Jean Vallianos of the American Chemistry Council for data on plastics end use.

\section{REFERENCES}

(1) UN-HABITAT. Cities and Climate Change: Policy Directions Abridged ed.; Earthscan: London, U.K., 2011.

(2) International Energy Agency. World Energy Outlook, 2008; International Energy Agency: Paris, France, 2008.

(3) Kennedy, C. A.; Ibrahim, N.; Hoornweg, D. Low-carbon infrastructure strategies for cities. Nat. Clim. Change 2014, 4 (5), 343-346.

(4) Ramaswami, A.; Bernard, M.; Chavez, A.; Hillman, T.; Whitaker, M.; Thomas, G.; Marshall, M. Quantifying carbon mitigation wedges in U.S. cities: near-term strategy analysis and critical review. Environ. Sci. Technol. 2012, 46 (7), 3629-3642.

(5) Mohareb, E. A.; Kennedy, C. A. Scenarios of technology adoption towards low-carbon cities. Energy Policy 2014, 66, 685-693.

(6) Hoornweg, D.; Sugar, L.; Trejos Gomez, C. L. Cities and greenhouse gas emissions: moving forward. Environ. Urban. 2011, 23 (1), 207-227.

(7) Ramaswami, A.; Hillman, T.; Janson, B.; Reiner, M.; Thomas, G. A demand-centered, hybrid life-cycle methodology for city-scale greenhouse gas inventories. Environ. Sci. Technol. 2008, 42 (17), 6455-6461.

(8) Kennedy, C.; Demoullin, S.; Mohareb, E. Cities reducing their greenhouse gas emissions. Energy Policy 2012, 49, 774-777.

(9) Seto, K. C.; Dhakal, S.; Bigio, A.; Blanco, H.; Delgado, G. C.; Dewar, D.; Huang, L.; Inaba, A.; Kansal, A.; Lwasa, S. et al. Chapter 12: Human Settlements, Infrastructure and Spatial Planning. In Climate Change 2014: Mitigation of Climate Change. Contribution of Working Group III to the Fifth Assessment Report of the Intergovernmental Panel on Climate Change; Edenhofer, O., Pichs-Madruga, R., Sokona, Y., Farahani, E., Kadner, S., Seyboth, K., Adler, A., Baum, I., Brunner, S., Eickemeier, P. et al., Eds.; Cambridge University Press: Cambridge, U.K., 2014.

(10) Bajželj, B.; Allwood, J. M.; Cullen, J. M. Designing climate change mitigation plans that add up. Environ. Sci. Technol. 2013, 47 (14), 8062-8069.

(11) Vermeulen, S. J.; Campbell, B. M.; Ingram, J. S. I. Climate Change and Food Systems. Annu. Rev. Environ. Resour. 2012, 37 (1), 195-222.

(12) McMichael, P. Food system sustainability: Questions of environmental governance in the new world (dis)order. Glob. Environ. Chang. 2011, 21 (3), 804-812.

(13) Lamb, A.; Green, R.; Bateman, I.; Broadmeadow, M.; Bruce, T.; Burney, J.; Carey, P.; Chadwick, D.; Crane, E.; Field, R.; et al. The potential for land sparing to offset greenhouse gas emissions from agriculture. Nat. Clim. Change 2016, 6, 488-492.

(14) Garnett, T. Where are the best opportunities for reducing greenhouse gas emissions in the food system (including the food chain)? Food Policy 2011, 36, S23-S32.

(15) Tilman, D.; Clark, M. Global diets link environmental sustainability and human health. Nature 2014, 515 (7528), 518-522.

(16) Wollenberg, E.; Richards, M.; Smith, P.; Havlík, P.; Obersteiner, M.; Tubiello, F. N.; Herold, M.; Gerber, P.; Carter, S.; Reisinger, A.; et al. Reducing emissions from agriculture to meet the $2^{\circ} \mathrm{C}$ target. Glob. Chang. Biol. 2016, 22 (12), 3859-3864.
(17) Kulak, M.; Graves, A.; Chatterton, J. Reducing greenhouse gas emissions with urban agriculture: A Life Cycle Assessment perspective. Landsc. Urban Plan. 2013, 111, 68-78.

(18) Thebo, A. L.; Drechsel, P.; Lambin, E. F. Global assessment of urban and peri-urban agriculture: irrigated and rainfed croplands. Environ. Res. Lett. 2014, 9 (11), 114002.

(19) Hillman, T.; Ramaswami, A. Greenhouse Gas Emission Footprints and Energy Use Benchmarks for Eight U.S. Cities. Environ. Sci. Technol. 2010, 44 (6), 1902-1910.

(20) Application of PAS 2070 - London, United Kingdom: An assessment of greenhouse gas emissions of a city; British Standards Institution: Bristol, U.K., 2014.

(21) Heinonen, J.; Kyrö, R.; Junnila, S. Dense downtown living more carbon intense due to higher consumption: a case study of Helsinki. Environ. Res. Lett. 2011, 6 (3), 034034.

(22) U.S. Census Bureau. 2010 Census Urban and Rural Classification and Urban Area Criteri. https://www.census.gov/geo/reference/ua/ urban-rural-2010.html (accessed January 19, 2016).

(23) Heller, M. C.; Keoleian, G. A. Greenhouse Gas Emission Estimates of U.S. Dietary Choices and Food Loss. J. Ind. Ecol. 2015, 19 (3), 391-401.

(24) USDA ERS. Food Availability. http://www.ers.usda.gov/dataproducts/food-availability-(per-capita)-data-system.aspx (accessed January 18,2016$)$.

(25) Centre for Transportation Analysis. National Household Travel Survey, 2009. http://nhts.ornl.gov/publications.shtml (accessed August 18,2016$)$.

(26) Energy Information Administration. Manufacturing Energy Consumption Survey, 2010. http://www.eia.gov/consumption/ manufacturing/data/2010/\#r1 (accessed August 30, 2017).

(27) U.S. Energy Information Administration. 2012 Commercial Building Energy Consumption Survey (CBECS) https://www.eia. gov/consumption/commercial/data/2012/index.cfm (accessed August 30, 2017).

(28) U.S. EIA. Residential Energy Consumption Survey (RECS) Data - U.S. Energy Information Administration (EIA) https://www. eia.gov/consumption/residential/data/2009/ (accessed August 30, 2017).

(29) Municipal Solid Waste Generation, Recycling, and Disposal in the United States: Facts and Figures for 2010; U.S. EPA: Washington, DC, 2011.

(30) Analysis of U.S. Food Waste Among Food Manufacturers, Retailers, and Wholesalers; The Food Waste Reduction Alliance: Washington, DC, 2014.

(31) U.S. Environmental Protection Agency. National Inventory Submissions, 2014. http://unfccc.int/national_reports/annex_i ghg inventories/national_inventories_submissions/items/8108.php (accessed August 30, 2017).

(32) IPCC. Revised 1996 IPCC Guidelines for National Greenhouse Gas Inventories; Houghton, J. T., Meira Filho, L. G., Lim, B., Treanton, K., Mamaty, I., Bonduki, Y., Griggs, D. J., Callander, B. A., Eds.; Intergovernmental Panel on Climate Change; U.K. Meteorological Office: Geneva, Switzerland, 1996.

(33) Mohareb, E. A.; MacLean, H. L.; Kennedy, C. A. Greenhouse Gas Emissions from Waste Management-Assessment of Quantification Methods. J. Air Waste Manage. Assoc. 2011, 61 (5), 480-493.

(34) Pipatti, R.; Alves, J. W. S.; Gao, Q.; Cabrera, C. L.; Mareckova, K.; Oonk, H.; Scheehle, E.; Sharma, C.; Smith, A.; Svardal, P.; et al. Chapter 4 - Biological Treatment of Solid. In 2006 IPCC Guidelines for National Greenhouse Gas Inventories; Eggleston, H. S., Buendia, L., Miwa, K., Ngara, T., Tanabe, K., Eds.; Institute for Global Environmental Strategies: Kanagawa, Japan, 2006; p 4.4.1-4.4.8.

(35) Boldrin, A.; Andersen, J. K.; Møller, J.; Christensen, T. H.; Favoino, E. Composting and compost utilization: accounting of greenhouse gases and global warming contributions. Waste Manage. Res. 2009, 27 (8), 800-812.

(36) U.S. EPA Waste Reduction Model (WaRM). http://www3.epa. gov/warm/ (accessed November 3, 2015). 
(37) Agarwala, R. T.; Desai, R.; Choy, B.; Fernandez, A.; Kirk, P.; Lazar, A.; Smith, T.; Watts, M.; Yan, A. Climate Action in Megacities: C40 Cities Baseline and Opportunities; Arup: Washington, DC, 2014; Vol. 2 .

(38) Hillman, T.; Ramaswami, A. Greenhouse gas emission footprints and energy use benchmarks for eight U.S. cities. Environ. Sci. Technol. 2010, 44 (6), 1902-1910.

(39) Weber, C. L.; Matthews, H. S. Food-miles and the relative climate impacts of food choices in the United States. Environ. Sci. Technol. 2008, 42 (10), 3508-3513.

(40) McClintock, N.; Cooper, J.; Khandeshi, S. Assessing the potential contribution of vacant land to urban vegetable production and consumption in Oakland, California. Landsc. Urban Plan. 2013, 111 (1), 46-58.

(41) Colasanti, K. J. A.; Hamm, M. W. Assessing the local food supply capacity of Detroit, Michigan. J. Agric. Food Syst. Community Dev. 2010, 1 (12), 41-58.

(42) USDA. USDA Food Waste Challenge. https://www.usda.gov/ oce/foodwaste/Challenge/index.htm (accessed May 2, 2017).

(43) Grocery Manufacturers Association. Food Waste Reduction Alliance. http://www.foodwastealliance.org/ (accessed May 2, 2017).

(44) Milan Urban Food Policy Pact; MUFPP Secretariat: Milan, 2015. (45) Levis, J. W.; Barlaz, M. a. What is the most environmentally beneficial way to treat commercial food waste? Environ. Sci. Technol. 2011, 45 (17), 7438-7444.

(46) Sanscartier, D.; Maclean, H. L.; Saville, B. Electricity Production from Anaerobic Digestion of Household Organic Waste in Ontario: Techno-Economic and GHG Emission Analyses. Environ. Sci. Technol. 2012, 46, 1233-1242.

(47) Mohapatra, D. P.; Cledón, M.; Brar, S. K.; Surampalli, R. Y. Application of Wastewater and Biosolids in Soil: Occurrence and Fate of Emerging Contaminants. Water, Air, Soil Pollut. 2016, 227 (3).7710.1007/s11270-016-2768-4

(48) Wygonik, E.; Goodchild, A. Evaluating the Efficacy of Shareduse Vehicles for Reducing Greenhouse Gas Emissions: A U. S. Case Study of Grocery Delivery. J. Transp. Res. Forum 2012, 51 (2), 111126.

(49) Dunn, S. Decarbonizing the energy economy; Norton, 2001.

(50) Kim, B.; Neff, R. Measurement and communication of greenhouse gas emissions from U.S. food consumption via carbon calculators. Ecol. Econ. 2009, 69 (1), 186-196.

(51) Weber, C. L.; Matthews, H. S. Food-miles and the relative climate impacts of food choices in the United States. Environ. Sci. Technol. 2008, 42 (10), 3508-3513.

(52) Vanham, D.; Mak, T. N.; Gawlik, B. M. Urban food consumption and associated water resources: The example of Dutch cities. Sci. Total Environ. 2016, 565, 232-239.

(53) Silver, L. D.; Ng, S. W.; Ryan-Ibarra, S.; Taillie, L. S.; Induni, M.; Miles, D. R; Poti, J. M.; Popkin, B. M. Changes in prices, sales, consumer spending, and beverage consumption one year after a tax on sugar-sweetened beverages in Berkeley, California, US: A before-andafter study. PLOS Med. 2017, 14 (4), e1002283.

(54) City of Philadelphia. Philadelphia Beverage Tax https://beta. phila.gov/services/payments-assistance-taxes/business-taxes/ philadelphia-beverage-tax/ (accessed May 2, 2017).

(55) Tilman, D.; Clark, M. Global diets link environmental sustainability and human health. Nature 2014, 515 (7528), 518-522.

(56) Oonincx, D. G. a B.; de Boer, I. J. M. Environmental Impact of the Production of Mealworms as a Protein Source for Humans - A Life Cycle Assessment. PLoS One 2012, 7 (12), e51145.

(57) Tuomisto, H. L.; de Mattos, M. J. T. Environmental impacts of cultured meat production. Environ. Sci. Technol. 2011, 45 (14), 61176123.

(58) Stevanović, M.; Popp, A.; Bodirsky, B. L.; Humpenöder, F.; Müller, C.; Weindl, I.; Dietrich, J. P.; Lotze-Campen, H.; Kreidenweis, U.; Rolinski, S.; et al. Mitigation Strategies for Greenhouse Gas Emissions from Agriculture and Land-Use Change: Consequences for Food Prices. Environ. Sci. Technol. 2017, 51 (1), 365-374.
(59) Kreycik, C. Financing Solar PV at Government Sites with PPAs and Public Debt; Golden, 2011.

(60) O'Shaughnessy, E.; Heeter, J.; Liu, C.; Nobler, E. Status and Trends in the U.S. Voluntary Green Power Market (2015 Data); Golden, Colorado, 2016.

(61) U.S. EPA. Local Utilities and Other Energy Efficiency Program Sponsors https://www.epa.gov/statelocalenergy/local-utilities-andother-energy-efficiency-program-sponsors (accessed Aug 21, 2017).

(62) Druckman, A.; Chitnis, M.; Sorrell, S.; Jackson, T. Missing carbon reductions? Exploring rebound and backfire effects in U.K. households. Energy Policy 2011, 39, 3572-3581. 